\title{
ANALISIS TRIPLE ROLE-MOSER DALAM KUMPULAN CERPEN JEJAK KOPIMU KARYA MIA ISMED
}

\author{
Endang Sulistyowati ${ }^{1}$, Noor Indah Wulandari ${ }^{2}$, \\ dan Muhlidinal Husna ${ }^{3}$
}

\author{
STKIP PGRI Banjarmasin ${ }^{1,2}$, Alumni PBSI STKIP PGRI Banjarmasin ${ }^{3}$ \\ email: Endangsulistyowati86@Stkipbjm.ac.id ${ }^{1}$ Indah_wulandari@Stkipbjm.ac.id², \\ Muhlidinalhusna@gmail.com ${ }^{3}$
}

\begin{abstract}
ABSTRAK
Penelitian ini tentang analisis Triple Role-Moser dalam kumpulan cerpen Jejak Kopimu karya Mia Ismed. Tujuan penelitian ini adalah untuk: 1) Mendeskripsikan peran reproduktif tokoh perempuan. 2) Mendeskripsikan peran produktif tokoh perempuan. 3) Mendeskripsikan peran sosial tokoh perempuan dalam cerpen Jejak Kopimu karya Mia Ismed.Pendekatan yang digunakan adalah pendekatan feminisime yang menginginkan adanya keadilan terhadap perempuan melalui monolog cerpen Jejak Kopimu. Metode dalam penelitian ini adalah deskriptif analisis. Sumber data penelitian ini kumpulan cerpen Jejak Kopimu karya Mia Ismed, diterbitkan oleh Tahura Media, Banjarmasin tahun 2017 dengan tebal buku 124 halaman. Teknik pengumpulan data penelitian ini dengan teknik baca, catat dan observasi teks. Sedangkan teknik analisis data dengan reduksi kata, penyajian dan penarikan simpulan. Hasil penelitian ini adalah ditemukannya peran-peran perempuan sesuai dengan teori triple role yang menganggap bahwa perempuan memiliki tiga peran yaitu peran reproduktif, produktif dan social yang terdapat dalam kumpulan cerpen Jejak Kopimu karya Mia Ismed. Sesuai dengan ketiga peran tersebut, berupa: 1) peran reproduktif meliputi: peran sebagai ibu, peran sebagai istri, peran sebagai single parent, peran sebagai nenek dan peran sebagai perempuan tunggal. 2) peran produktif meliputi: peran sebagai penjual kue, peran sebagai pemulung, peran sebagai pedagang kaki lima, peran sebagai perempuan panggilan, peran pengusaha tenun, peran penjual lontong dan peran sebagai guru kontrak. 3) peran sosial meliputi: peran dalam pelatihan menjahit, peran dalam memberi makan jemaah Jumat, peran dalam ikut les, peran dalam keaktifan menulis di media dan peran sebagai mahasiswa.
\end{abstract}

Kata Kunci : triple-role, peran perempuan, kritik sastra feminisme

\section{PENDAHULUAN}

Sastra merupakan sebuah cerita fiksi yang berasal dari luapan imajinasi, diungkapan melalui tulisan dengan dibumbui racikan khas gaya pengarangnya. Sastra juga diangkat melalui pengalaman batin pengarang dari berbagai problematika kehidupan pribadi hingga peristiwa kehidupan di masyarakat yang dijadikan sebagai gagasan dalam penulisannya. Oleh karena itu, sastra tidak dapat lepas dari rekam jejak dalam kehidupan bermasyarakat dengan memberikan berbagai macam nilai.

Dari berbagai jenis sastra, cerpen adalah salah satunya. Cerpen berisi cerita tentang peristiwa dalam kehidupan manusia, di dalamnya mengandung makna yang dapat dipetik oleh pembaca. Salah satu bentuk cerpen yang dijadikan objek penelitian yaitu cerpen karya Mia Ismed 
dengan judul Jejak Kopimu. Dalam kumpulan cerpen tersebut, semuanya memiliki pemeran tokoh perempuan dengan berbagai problematika kehidupan sehari-hari yang diluapkan ke dalam bentuk tulisan. Berbagai status dan profesi pemeran tokoh perempuan seperti seorang ibu rumah tangga, perempuan tunggal, pemulung, perempuan panggilan, pedagang kaki lima, tenaga pendidik, mahasiswa dan sebagai seorang anak.

Berdasarkan masalah tersebut memicu terjadinya sebuah ketimpangan gender, ketika perempuan memiliki multiperan atau dalam istilah triple role yaitu perempuan yang mengemban peran produktif, peran reproduktif, dan peran sosial. Pada kenyataannya, perempuan masih dideskriminasi, perempuan tetap dianggap sebagai kaum yang lemah, bahkan dalam sebuah istilah menyebutkan bahwa tugas perempuan tidak boleh lebih dari sekedar di dapur, di sumur dan di kasur.

Penelitian peran perempuan tidak dapat dipisahkan dengan feminisme. Perkembangan dan penyebaran feminisme memunculkan istilah-istilah mengenai definisi feminisme dari beberapa tokoh baik dari mancanegara maupun dari dalam negeri. Ratna (Rahmah, 2015:57) mendefinisikan feminisme secara luas bahwa, "feminisme merupakan sebuah gerakan kaum wanita yang menolak segala sesuatu yang direndahkan oleh kebudayaan dominan dalam segala bidang”. Berbeda dengan pendapat Humm (Wiyatmi, 2017:10) menganggap secara sederhana bahwa "feminisme mengacu pada aliran pemikiran atau ideologi yang menginginkan adanya keadilan dan kesetaraan gender. Karena cita-citanya tersebut, maka feminisme dianggap sebagai ideologi pembebasan perempuan, yang berangkat dari keyakinan bahwa perempuan telah mengalami ketidakadilan karena jenis kelaminnya. Feminisme menawarkan berbagai analisis mengenai penyebab dan pelaku dari penindasan perempuan." Sedangkan Muthahhari (2012:5) memandang bahwa "feminisme sebagai suatu kesadaran akan penindasan dan pemerasan terhadap masyarakat, baik itu di dalam tempat kerja ataupun keluarga, serta tindakan sadar oleh perempuan dan laki-laki untuk mengubah keadaan tersebut".

Kehadiran feminsme menghadirkan kritik sastra feminisme dengan memiliki sejumlah pengertian, seperti yang dikemukakan oleh Wiyatmi (2017:15) "kritik sastra feminis adalah salah satu ragam kritik sastra yang mendasarkan pada pemikiran feminisme, yaitu kritik sastra yang menginginkan adanya keadilan dan kesetaraan gender dalam memahami karya sastra maupun penulisnya". Dengan memfokuskan pada isu-isu gender yang diekspresikan dalam karya sastra kritik sastra feminis mencoba membongkar dan memahami berbagai hal yang berhubungan dengan keadilan dan kesetaraan gender. 
Salah satu objek kajian kritik sastra feminisme adalah dari segi peran perempuan. Munculnya peran perempuan berasal dari pembagian kerja yang didasarkan pada jenis kelamin yang lebih populer dengan istilah gender. "Gender merupakan suatu sifat yang dijadikan dasar untuk mengidentifikasi perbedaan antara laki-laki dan perempuan dilihat dari segi kondisi sosial dan budaya, nilai dan perilaku, mentalitas, dan emosi serta faktor nonbiologis lainnya" (Rokhmansyah, 2016:1). Tafsiran mengenai munculya peranan perempuan yang kategorikan menjadi tiga peranan atau triple role. Shah (2010:70) memberikan konsep bahwa triple role sebagian besarnya berasal dari pada debat golongan feminist dalam meluaskan literatur hubungan gender di Dunia Pertama dan Dunia Ketiga. Ia juga timbul kesan daripada penyelidikan ke atas wanita di negara Dunia Ketiga

Penggunaan ketiga peranan ini penting untuk menilai peranan wanita di dalam dan luar rumah. Ketiga peran ini juga digunakan untuk mengenal pasti apa yang dilakukan oleh wanita setiap hari di dalam kehidupan mereka, yang mana sebelum ini tidak kelihatan atau kurang diberi tumpuan. Perbincangan seterusnya memperincikan tiga peranan yang dikenal pasti oleh O.N. Caroline Moser. Sebagaimana dikemukakan Moser (Daeli, 2010:3-4) "mengemukakan adanya tiga kategori peranan gender (triple roles) yang mencakup peranan produktif, reproduktif dan pengelolaan masyarakat".

Peran Reproduktif berkaitan dengan bagaimana perempuan menjalankan perannya dalam memperhatikan dan memelihara rumah tangga dan seluruh anggota keluarga, termasuk merawat anak-anak, persiapan makanan, air, bahan bakar, persediaan alat dan perlengkapan rumah tangga, serta menjaga kesehatan keluarga. pekerjaan produktif sangat penting untuk kelangsungan hidup manusia dalam pemeliharaan dan reproduksi tenaga kerja. Peran produktif berhubungan dengan proses produksi barang-barang konsumsi atau generasi pendapatan melalui kerja di dalam atau di luar rumah. Peran masyarakat dibagi menjadi dua jenis yaitu peran pengelolaan masyarakat dan peran politik masyarakat. Peran pengelolaan masyarakat adalah tipikal pekerjaan sukarela yang banyak dilakukan oleh perempuan untuk mengisi waktu bebas, misalnya mengikuti organisasi kolektif kegiatan sosial, jasa upacara atau perayaan, aktivitas peningkatan kualitas masyarakat partisipasi dalam kelompok klub, dan masih banyak lagi.

\section{METODE}

Penelitian ini menggunakan pendekatan feminisme yang sering pula disebut dengan istilah kritik sastra feminisme, sedangkan jenis penelitiannya yaitu penelitian kepustakaan. Penelitian 
kepustakaan (library research) adalah serangkaian kegiatan yang berkenaan dengan metode pengumpulan data pustaka-pustaka, membaca sumber-sumber pustaka dan mencatat hasilnya, kemudian mengelola bahan penelitian (Zed dalam Watsiqotul, dkk, 2018:365).

Metode yang digunakan yaitu deskriptif analaitis. Ratna (2004:53) mengatakan bahwa "metode deskriptif analitik dilakukan dengan cara mendeskripsikan fakta-fakta yang kemudian disusul dengan analisis". Penelitian ini difokuskan terhadap tiga peran perempuan atau triple role dalam kumpulan cerpen Jejak Kopimu karya Mia Ismed yaitu peran reproduktif, peran produktif dan peran sosial. Cerpen Jejak Kopimu merupakan sumber data penelitian dalam yang diterbitkan oleh Tahura Media, Banjarmasin tahun 2017 dengan tebal buku 124 halaman.

Teknik pengumpulan data dalam penelitian ini menggunakan teknik baca, catat dan observsi teks. Teknik analisis data dengan cara Reduksi Data, Penyajian Data dan Penarikan simpulan. Untuk mempermudah pengumpulan data, peneliti membuat ke dalam kartu penjaring data untuk menjaring seluruh data agar mempermudah mengetahui jumlah peran perempuan sesuai kategori yang sudah ditentukan. Berikut kartu data yang akan digunakan.

Tabel 1.

Contoh Kode Data

\begin{tabular}{|c|l|l|l|l|l|c|}
\hline No & Peran Perempuan & Data & $\begin{array}{r}\text { Judul } \\
\text { Cerpen }\end{array}$ & $\begin{array}{c}\text { Nomor } \\
\text { Data }\end{array}$ & Halaman & Kode \\
\hline 1 & $\begin{array}{l}\text { Peran } \\
\text { Reproduktif (PR) }\end{array}$ & Sebagai ibu & Lapak & 5 & 55 & LP.PR5: 2014: 55 \\
\hline 2 & $\begin{array}{l}\text { Peran } \\
\text { Produktif (PP) }\end{array}$ & & & & & \\
\hline 3 & Peran Sosial (PS) & & & & & \\
\hline
\end{tabular}

Contoh kode data: LP.PR5: 2014: 55 adalah judul buku Lapak kode data ke lima peran produktif terletak pada halaman 55 .

\section{HASIL DAN PEMBAHASAN}

\section{Peran Reproduktif dalam Kumpulan Cerpen Jejak Kopimu Karya Mia Ismed}

\section{Perempuan sebagai Ibu}

[1] "Dia ibu yang hebat bagi anak dan suaminya. Ya, dia wanita hebat melahirkan anakanak hebat. Tapi kenapa aku menyia-nyiakannya hanya karena hawa nafsuku belaka?" sesal ayah.” (DI.PR1:2014:3)

Dari kutipan cerita [1] merupakan penyesalan seoarang suami terhadap istrinya, seperti yang ia sesalkan dia wanita hebat melahirkan anak-anak hebat. Suaminya menceritakan bahwa istrinya 
merupakan sosok ibu yang hebat terhadap anak-anaknya, ia menganggap telah melahirkan anak-anak yang hebat.

[2] "19 September 2001; Aku sangat bahagia, Tuhan memberikan sebuah cinderamatanya untuk rumah tanggaku. Seorang gadis mungil yang keluar dari rahimku. Gadis itu cucu semata wayang keluarga subrata. Mayang kinaryasih Subrata, nama yang disematkan suamiku." (DI.PR2:2014:4)

Kutipan cerita [2] menunjukkan bahwa perempuan sudah memiliki seorang anak yang diceritakan melalui diarynya. Anak pertamanya dilahirkan pada 19 September 2001. Kebahagiaan seorang ibu setelah ia menikah akhirnya dianugrahi seorang anak sebagai cinderamatanya untuk rumah tangganya.

[3] "Desember 2002; Putri kedua kita lahir meski harus menghirup udara beberapa jam dan akhirnya yang kuasa lebih sayang dan memanggilnya, Ayu Kinanthi Subrata, sehingga kau menjadi bidadari di surgaNya, Nak." (DI.PR3:2014:5)

Kutipan cerita [3] merupakan kelahiran anak keduanya pada Desember 2002 setelah berselang satu tahun dari anak pertamanya. Ibu yang melahirkan merupakan salah bagian dari peran perempuan setelah melaksanakan perkawinan.

[4] "Ini, Nak, uangnya. Cepat bayarkan untuk membeli kaus seragam sekolahmu. Jangan lupa, jika ada sisa uangnya ditabung, ya...." suara ibu lembut dengan tatapan sayang." (GT.PR4:2014:8)

Kutipan cerita [4] menunjukkan peran seorang perempuan sebagai ibu yang sangat peduli terhadap pendidikan anakknya. Ibunya memberikan uang kepada anaknya untuk membiayai pembayaran kaos seragam sekolahnya. Hal tersebut hanya untuk keberlangsungan pendidikan anakknya. Ibunya sosok yang begitu menyayangi anaknya dengan menampakkan tatapan sayang dengan suara yang lembut.

[5] "Bagaimana, Risky, kamu masih marah dengan ibumu? Kamu masih ingin meninggalkan orang yang bekerja tak pernah lelah untuk hidupmu? (GT.PR5:2014:12)

Kutipan cerita [5] merupakan dialog antara pemuda dengan Risky, ia menyadarkan kepada Risky bahwa ibunya merupakan sosok ibu yang bekerja tak kenal lelah guna keperluan hidup dan kebahagiaan anaknya. Pemuda tersebut menyadarkan kepada Risky agar tak selalu menyesali kehidupannya yang miskin sehingga tidak menerima kehidupannya yang serba kekurangan.

[6]".. Aku bersyukur lapakku kini berdiri kokoh, mendendangkan cita-cita buah hatiku, juga masa tua emakku. (LP.PR6:2014:26)

Kutipan potongan cerita [6] merupakan peran perempuan yang memiliki seorang anak yang dianggap sebagai seorang buah hati. Ia merasa bersyukur bisa memiliki apa yang ia punya, memiliki 
lapak yang resmi tanpa ketakutan akibat adanya penertiban, tinggal bersama emaknya yang sudah mulai tua dan menjadi ibu yang bahagia terhadap buah hatinya.

\section{Perempuan sebagai Single Parent}

[7] "Kuakui, semenjak menjadi single parent untuk putra semata wayangku, hidupku seakan limbung. Lelaki itu sudah pergi meninggalkanku mega-mega yang membawanya ke bulan..." (SPB.PR7:2014: 75)

Kutipan cerita [7] merupakan sebuah pernikahan menjadi berantakan hingga berujung perceraian mengakibatkan seorang perempuan semakin terbebani terhadap peran yang ia pikul. Menjadi single parent yang mempunyai seorang anak ditinggal oleh suaminya merasakan kehidupan yang limbung. Suaminya yang dulu kini sudah meninggalkannya dengan kehidupannya yang baru laki-laki yang membuatnya jatuh hati.

[8] "kakek Abdullah suami Ibu Saodah adalah seorang ustadz di kampung itu. Dimasa hidupnya kakek mendirikan masjid tepat di muka rumahnya. Kakek Abdullah adalah seorang imam masjid sekaligus guru mengaji. Sepeninggalan kakek Abdullah, Nenek Saodah istiqomah memberikan sedekah dan menjaga masjid yang dibangun suaminya" (MB.PR8:2014:55).

Kutipan [8] tersebut, perempuan tersebut berpisah dengan suaminya lantaran suaminya terlebih dahulu menemui ajalnya. Suami ia bernama Abdullah, dulunya seorang ustad, imam masjid dan juga guru mengaji. Suaminya juga saat itu mendirikan masjid tepat di depan rumahnya

\section{Perempuan sebagai Istri}

[9] "ayah tampak semakin menyesali keadaan ini. Ibuku, istrinya yang dulu dia tinggalkan adalah wanita manis, sederhana, tangguh dan baik.” (DI.PR9:2014:3)

Kutipan cerita [9] menganggap bahwa sosok istri yang ia tinggalkan adalah wanita manis, sederhana, tangguh dan baik seperti yang ia sampaikan bahwa istrinya wanita manis, sederhana, tangguh dan baik. Dari keadaan tersebut tak dapat ia pungkiri bahwa ia telah meninggalkan sosok istri yang sempurna dengan segala kelebihan yang dimilikinya.

[10] "10 Agustus 2000; hari ini aku bahagia sekali. Seorang gadis desa yang dipersunting pemuda tampan yang bermartabat. Terimakasih ya Allah, ini mungkin jawaban dari doa dan pengorbananku selama ini" (DI.PR10:2014:4)

Kutipan cerita [10] merupakan seorang perempuan yang dinikahkan dengan seorang pemuda yang tampan dan bermartabat. Dalam diarynya menikah pada 10 Agustus 2000 yang 
merupakan hari kebahagiaan dalam kehidupannya. Rasa syukur ia ucapkan kepada-Nya atas kebahagia yang telah diberikan kepadanya.

[11] “...Setiap keliling mencari plastik bekas minuman dengan gerobak dorong. Tak pernah tertinggal bungkusan plastik hitam berisi mukena. Ibu tak pernah meninggalkan salat lima waktu." (GT.PR11:2014:8)

Potongan kutipan [11] menunjukkan peran istri yang selalu sayang terhadap keluarganya, baik kepada anak maupun kepada suaminya. Bahkan istrinya melarang suaminya untuk tidak terlalu banyak beraktivitas dalam bekerja, lantaran sang istri perduli terhadap kesehatan suaminya.

[12] “... Mereka sangat mengenali gerobak ibu. Mereka menendang gerobak ibu hingga terjungkal. Saat itu ibu sedang ke puskesmas membawa berobat. Aku hanya membisu menyaksikan ejekan-ejekan itu" (GT.PR12:2014:10)

Potongan cerita [12] merupakan peran perempuan sebagai wujud kecintaan terhadap suaminya, ia merawat suaminya dan membawanya ke puskesmas untuk berobat dengan harap suaminya bisa sembuh dari penyakit yang dideritanya. Ia mengurus suaminya pada saat ia pulang dari pekerjaannya.

[13]"semenjak kembali ke kampung halaman, kuakhiri masa lajangku. Seorang lelaki berprofesi sebagai pedagang pakaian telah menyuntingku. Mulai saat itulah kehidupanku berubah warna. Kuberanikan membuka diri membawa lapak nasib di Pasar Wonosari....”( LP.PR13:2014:26)

Kutipan cerita [13] merupakan peran perempuan menjadi seorang istri, ia menikah dengan seorang lelaki yang bekerja sebagai seorang pedagang pakaian. Pada saat itulah ia mengakhiri masa lajangnya. Seusai pernikahannya, ia merasa kehidupannya kian mulai berubah menjadi lebih baik, ia mendirikan lapak yang kokoh di pasar wonosari.

\section{Perempuan sebagai Nenek}

[14]"... Sejak kecil Maksum diasuh neneknya, Saodah. Ayah dan ibunya sudah lama meninggalkannya. Bukan pergi melepas tanggung jawab, akan tetapi kerata naas yang ditumpangi ketika mudik dari ibukota terguling. Semasa hidup, ayah dan ibunya mengadu nasib di ibukota sebagai pedagang warung kopi. (MB.PR14:2014:53)

Peran yang dilakukan perempuan dalam kutipan [14] sebagai seorang nenek yang tinggal bersama cucunya yang bernama Maksum. Anak yang tinggal bersama nenek Saodah memang sudah dari kecil bersamanya, ibu dan bapaknya telah meninggal karean kereta yang ia tumpangi saat mudik terbalik sehingga merenggut nyawa mereka bersua.

[15]"Maksum dibesarkan nenek Saodah dengan hidup sederhana. Kebetulan maksum bukanlah anak yang manja seperti bocah kebanyakan. Sepulang sekolah ia selalu membantu neneknya mencari kayu bakar di perbukitan. Tak hanya itu, ia juga mencari 
rumput untuk ternak kambing yang sudah hampir dua tahun dibesarkannya di kandang belakang pekarangan..." (MB.PR11:2014:55) (MB.PR15:2014:55)

Kutipan cerita [15] merupakan peran yang dilakukan oleh neneknya dalam mengurus maksum hingga ia besar. Cucunya bukan seperti anak kebanyakan yang memiliki sifat yang manja, namun cucunya anak yang rajin membantu neneknya karena sejak ia kecil dibesarkan dengan kehidupan yang sederhana. Maksum sering membantu neneknya dalam mencari kayu bakar di perbukitan.

\section{Perempuan sebagai Perempuan Tunggal}

[16]“..Di atas tungku mengepul nasi yang akan diperdagangkan siang menjelang sore nanti. Piring-piring yang sedari tadi kucuci pun sudah berjajar rapi di etalase kayu yang dibuat bapak dari kampung. Di ibukota ini hanya aku yang menemani emak membuka lapak mengadu peruntungan..."( LP.PR16:2014:24)

Potongan cerita [16] merupakan peran seorang anak sebagai perempuan tunggal yang mengurus dirinya sendiri sekaligus membantu keluarganya. Ia menemani emaknya mengadu nasib di ibukota untuk mencari rezeki. Ia membantu emaknya mengurus dagangannya dan merapikan perabotan keperluan lapaknya. Ia memiliki beberapa adik yang ditinggal dikampung bersama simbah, sedangkan bapaknya sering sakit-sakitan hanya seorang buruh kuli bangunan.

[17]"Iya, dia masih sendiri. Dia anak baik. Semenjak ibu meninggal, dia melanjutkan usaha tenun bapaknya." (PK.PR17:2014:44)

Kutipan cerita [17] merupakan peran seorang anak yang tinggal bersama bapaknya, sedangkan ibunya sudah meninggal dunia. Dalam konteks reproduktif, perempuan tersebut harus menjalankan kehidupannya bersama bapaknya semenjak meninggal dunia. Ia juga merupakan sosok perempuan yang baik yang masih berstatus lajang.

[18]“Tak lama Fatimah datang lagi dengan membawa nampan dengan cangkir minuman. "Monggo Kang. Tehnya diminum" Fatimah meletakkan cangkir poci khas kampung ini” (PK.PR18:2014:46)

Kutipan cerita [18] terjadi ketika ada seorang pemuda yang bertamu di rumahnya, ia memberikan pelayanan terhadap tamunya dengan membawakan nampan yang berisikan secangkir minuman. Ia memberikan minuman teh yang diletakkan pada cangkir poci khas di kampungnya. Pelayanan kepada tamu tersebut sebagai kegiatan reproduktif dalam hal menyajikan hidangan minuman teh terhadap tamunya. 


\section{Peran Produktif dalam Kumpulan Cerpen Jejak Kopimu Karya Mia Ismed}

\section{Perempuan sebagai Penjual Kue}

[1]"Desember 2003; Kubuka kios kueku yang kian manis menebarkan rayu mata memandang. Juga senyum yang selalu kusuguhkan kepada setiap pengunjung yang setia menanti menu istimewa sajian kiosku..." (DI.PP1:2014:5)

Kutipan cerita [1] melakukan pekerjaaan sebagai penjual kue di koisnya. Ia memberikan pelayanan yang baik kepada setiap pengunjungnya. Perempuan tersebut menceritakan pekerjaannya dalam diarenya pada Desember 2003.

\section{Perempuan sebagai Pemulung}

[2] “...Meski aku anak pemulung, tapi ibu tetap ingin aku sekolah. Bapak sakit-sakitan Bapak hanya mampu memulung sesekali saja. Asmanya selalu kambuh itu sebabnya Ibu tak mengijinkan ayah bekerja terlalu capek...." (GT.PP2:2014:7)

Potongan cerita [2] merupakan salah satu pekerjaan perempuan sebagai pemulung. Tantangan kehidupan yang keras mengharuskannya untuk terlibat dalam ranah produktif, ia harus bekerja agar dapat memenuhi kebutuhan makan, minum, pendidikan anaknya dan kebutuhan lainnya.

\section{Perempuan sebagai Pedagang Kaki Lima}

[3]"aku semakin tak mengerti ketika piring-piring itu menjadi korban atas nasibku. Lantas apa salah lapakku ini? Apakah ia dikhawatirkan menjadi markas dan aku dihakimi seperti layaknya teroris meresahkan? (LP.PP3:2014:23)

Potongan cerita [3] merupakan peran perempuan yang menjadi seorang pedagang kaki lima. Ia menjadi korban terhadap penertiban oleh aparat bersama pedagang lapak lainnya. Barang-barang hingga lapak yang ia miliki ikut dirusak oleh aparat. Ia merasa mengapa dianggap menjadi orang yang meresahkan bagi pemerintah, bahkan ia seperti teroris yang membuat kekhawatiran.

\section{Peran sebagai Perempuan Panggilan}

[4] "kamu yakin tak mau bersenang-senang denganku? Aku tak ingin makan gaji buta lo..." (LL.PP4:2014:32)

Kutipan cerita [4] di atas terjadi saat perempuan panggilan sedang berkencan dengan tamunya. Tokoh perempuan beberapa kali memancing tamunya untuk bercinta seperti tamu yang lainnya, namun lelaki yang dikencaninya saat ini selalu menolaknya. 


\section{Perempuan sebagai pengusaha Tenun}

[5] "Iya, dia masih sendiri. Dia anak baik. Semenjak ibu meninggal, dia melanjutkan usaha tenun bapaknya." (PK..PP5:2014:44)

Kutipan cerita [5] menunjukkan peran perempuan sebagai seorang pengusaha tentun yang melanjutkan usaha bapaknya setelah ibunya sudah meninggal. Ia merupakan seorang gadis yang masih sendiri tanpa ada seorang pasangan. Sebelumnya ia memang seorang anak pengusaha tenun, namun kali ini ia hanya melanjutkan usaha tersebut.

\section{Perempuan sebagai Penjual Lontong}

[6] "... Setiap jumat nenek Saodah tak pernah absen memberi makan bagi jemaah salat jumat. Nenek Saodah se tiap hari berjualan lontong sayur di pasar wonosari. Hari liburnya adalah hari jumat, sebagai pernghormatan beliau untuk memberikan hidangan cuma-cuma bagi jemaah. (MB.PP6:2014:55)

Potongan kutipan cerita [6] merupakan seorang nenek yang berjualan lontong sayur di pasar wonosari. Setiap hari ia berjualan di pasar tersebut untuk mencari pundi-pundi rupiah, namun ia berlibur pada hari jumat karena hari tersebut khusus untuk memberi makan jamaah salat jumat.

\section{Perempuan sebagai Guru Kontrak}

[7] "Pertemuan yang singkat kala itu memudarkan kepercayaanku terhadap lelaki. Perkawinanku kandas. Sejak itulah aku memutuskan untuk menjadi guru kontrak di daerah pedalaman. ... (SPB.PP7:2014:75)

Kutipan cerita [7] merupakan peran perempuan menjadi seorang pendidik dengan status sebagai guru kontrak. Pengabdian menjadi guru yang ia lakukan di sebuah daerah pedalaman.

\section{Peran Sosial dalam Kumpulan Cerpen Jejak Kopimu Karya Mia Ismed}

\section{Perempuan dalam Pelatihan Menjahit}

[1] "Beberapa kali pertemuan selepas Ashar sepulang dari sawah atau pasar mereka sangat antusias ke rumah belajar. Setiap minggu di kantor desa kami menjadwalkan materi keterampilan menjahit bagi masyarakat, khususnya ibu-ibu. Tak terkecuali Fatimah, dia selalu hadir sebagai pioneer diantara mereka." (PK..PS1:2014:50)

Kutipan cerpen [1] menunjukkan bahwa perempuan dalam cerpen tersebut digambarkan sebagai seorang pioneer atau penggagas dalam pelatihan keterampilan menjahit di desanya. Kegiatan sosial tersebut dilaksanakan di kantor desa selama satu minggu sekali. 


\section{Perempuan dalam Memberi Makan Jemaah Salat Jumat}

[2]"'Tetapi keteguhah keluarga nenek Saodah membangun agama Allah sangat diperhitungkan. Setiap jumat nenek Saodah tak pernah absen memberi makan bagi jemaah salat jumat." (MB.PS2:2014:55)

Kutipan cerpen [2] menggambarkan bahwa peran sosial yang dilakukan nenek Saodah berupa memberi makan bagi jemaah salat jumat. Hal tersebut sebagai bentuk kegiatan sosial yang melibatkan masyarakat sebagai tujuan utamanya dalam membagikan rezekinya karena ia menyadari segala bentuk yang dimilikinya hanyalah titipan oleh-Nya.

\section{Perempuan dalam Keikutsertaan Les}

[3]"...tapi, sejak perusahaan papa gulung tikar, aku tidak siap dengan kondisiku yang serba kekurangan. Dari kecil aku terbiasa hidup mewah. Hampir semua les aku ikuti."(LL.PS3:2014:33)

Potongan cerpen [3] menceritakan bahwa dulu ketika kehidupannya yang mewah, ia berpartisipasi dalam mengikuti semua berbagai pelatihan les guna peningkatan kualitas dirinya. Pelatihan les tersebut sebagai bentuk aktivitas untuk mengisi waktu agar mendapatkan sebuah pengetahuan dari berbagai kegiatan yang ia ikuti.

\section{Perempuan dalam Keaktifan di Media Sosial}

[4] “...Karena tak kujumpai lagi kamu di media itu.... Ah terlalu berlebihan. Dulu aku memang aktif mengisi kolom budaya di harian kota dan bermain-main dengan anakanak di TIM. Tapi sekarang, entahlah..” ( LL.PS4:2014:33-34)

Peran perempuan pada kutipan [4] merupakan peran sosial yang dilakukan berupa keaktifannya dalam menulis di media sosial seperti di surat kabar nasional, kolom budaya di harian kota serta di media sosial pribadinya.

\section{Perempuan Sebagai Mahasiswa}

[5] “iya, aku masih kuliah. Sudahlah, jangan tanyakan semester berapa. Sudah kadaluarsa mahasiswa seperti aku ini”( LL.PP5:2014:32)

kutipan cerita [5] merupakan bagian dari usaha untuk meningkatkan kualitas dirinya dari berbagai aspek seperti pengetahuan, pengalaman dan lainnya. Usaha tersebut akan menjadi 
penunjang ketika melanjutkan karirnya dalam memperoleh pekerjaan yang lebih layak setelah ia lulus.

\section{SIMPULAN}

Hasil pembahasan yang diperoleh pada cerpen Jejak Kompimu karya Mia Ismed, yaitu: Peran reproduktif, meliputi: peran sebagai ibu, peran sebagai istri, peran sebagai single parent, peran sebagai nenek dan peran sebagai perempuan tunggal. Peran produktif, meliputi: peran sebagai penjual kue, peran sebagai pemulung, peran sebagai pedagang kaki lima, peran sebagai perempuan panggilan, peran pengusaha tenun, peran penjual lontong dan peran sebagai guru kontrak. Peran sosiaL, meliputi: peran dalam pelatihan menjahit, peran dalam memberi makan jemaah jumat, peran dalam ikut les, peran dalam keaktifan menulis di media dan peran sebagai mahasiswa.

\section{DAFTAR RUJUKAN}

Daeli, J. G. 2013. Peran Gender Perempuan dalam Film Seri The Hunger Games. Jurnal EKomunikasi. 1(1):2-11.9, (Online), (https://publication.petra.ac.id/index.php/ ilmukomunikasi/article/view/7084, diakses 24 Mei 2019).

Ismed, M.. 2017. Jejak Kopimu. Banjarmasin: Tahura Medika.

Moser, O.N. Caroline. (1993). Gender Planning and Development Theory: Practice and Training. London: Routledge.

Muthahhari, M.. 2012. Filsafat Perempuan dalam Islam. Yogyakarta: Rausyanfikir Institute.

Rahmah, Y. 2015. Cerpen “Koros hiya Desu No Yo” Sebuah Kajian Feminisme. Izumi, 4(2):56-68. (Online),(https://ejournal.undip.ac.id/index.php/izumi/article/view/9931, diakses 24 mei 2019)

Ratna, N. Ka. 2009. Teori, Metode, dan Teknik Penelitian Sastra dari Strukturalisme Hingga Posrukturalisme Perspektif Wacana Naratif. Yogyakarta: Pustaka Pelajar

Rokhmansyah, A. 2016. Pengantar Gender dan Feminisme. Yogyakarta. Garudhawacana.

Shah, J. M.. 2010. Triple Role: Suatu Penyingkapan Peranan dan Kerja Wanita. Jurnal Sosiohumanika, 3(1):67-78. (Online), (http://journals.mindamas.com/index.php/ sosiohumanika/article/view/404, diakses 3 Januari 2019)

Tim Penyusun. 2016. Pedoman Penulisan Skripsi. Banjarmasin: STKIP PGRI. 
Watsiqotul, dkk. 2018. Peran Manusia Sebagai Khalifah Allah di Muka Bumi Perspektif Ekologis dalam Ajajaran Islam. Jurnal Penelitian, 12(2):355-378. (online) (http://journal.stainkudus.ac.id/index.php/jurnalPenelitian/article/view/3523, diakses 4 Januari 2019)

Wiyatmi. 2017. Perempuan dan Bumi dalam Sastra: dari Kritik Sastra Feminis, Ekokritik, sampai Ekofeminis. Yogyakarta: Cantrik Pustaka. 